\title{
Anticlastogenic properties of Quercus infectoria galls extract against DMBA induced genotoxicity in bone marrow cells of mice in vivo
}

\author{
S.I. Amedi ${ }^{1}$ and B.M. Mohammed ${ }^{2}$ \\ ${ }^{1}$ Department of Pathology and Microbiology, College of Veterinary Medicine, ${ }^{2}$ Department of Biology, College of Science, \\ University of Duhok, Duhok, Iraq, Email: ${ }^{1}$ sherzad_vet7@yahoo.com, ${ }^{2}$ bushra.mohammed@uod.ac
}

(Received July 16, 2019; Accepted September 30, 2019; Available online May 21, 2020)

\begin{abstract}
This study aimed to evaluate the aqueous extract of Quercus infectoria galls extract (QIGE) as anticlastogenic. The effect of QIGE was tested in mice (5 groups for each test) treated with 7, 12-dimethylbenz (a) anthracene (DMBA), the strong sitespecific carcinogenic agent. In this study, the QIGE show no signs of toxicity, a single dose of DMBA $(50 \mathrm{mg} / \mathrm{kg})$ was injected intraperitoneally to Swiss albino mice caused a great increase in number of chromosomal aberrations, micronucleated polychromatic erythrocytes (MnPCEs) and reduction in the percentage of mitotic index (MI) (cytogenetic markers). Oral pretreatment and post-treatment of QIGE for 14 days at dose $2 \mathrm{gm} / \mathrm{kg}$ b.w. daily to DMBA-treated animals greatly reduced in number of micronucleus formation, chromosomal abnormalities such as chromosomal break, chromatid breaks, ring chromosome, dicentric chromosome and fragments. Besides, mitotic index frequency increased comparing with the positive control. The data suggest that QIGE has potent anti-clastogenic effect against DMBA-induced genotoxicity in bone marrow cells of albino male mice and it may have a protective effect against the mutagenicity of the polynuclear aromatic hydrocarbons $(\mathrm{PAH})$.
\end{abstract}

Keywords: Quercus infectoria galls, Anticlastogenic, Mutagenicity, Chromosome aberration, Micronucleus

Available online at http://www.vetmedmosul.com, () 2020, College of Veterinary Medicine, University of Mosul.

This is an open access article under the CC BY 4.0 license (http://creativecommons.org/licenses/by/4.0/).

\section{الخواص المضادة للطفرات الكروموسومية لعفص البلوط Quercus infectoria ضد السمية الوراثية

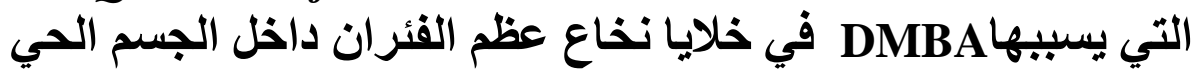 \\ شيرزاد إبراهيم العمادي' و بشرى محمدأمين محمد`}

' فرع الأمر اض و الأحياء المجهرية، كلية الطب البيطري، ؟ قسم علم الأحياء، كلية العلوم، جامعة دهوك، دهوك، العراق

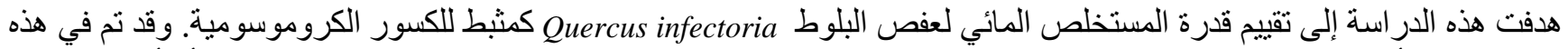

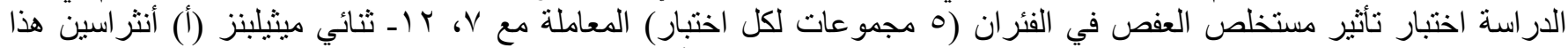

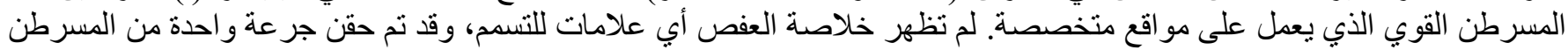

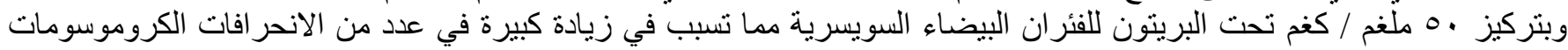

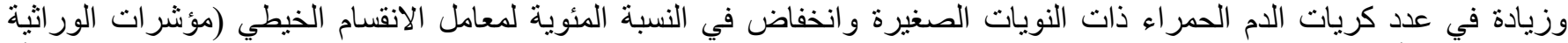

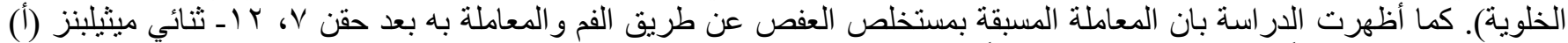

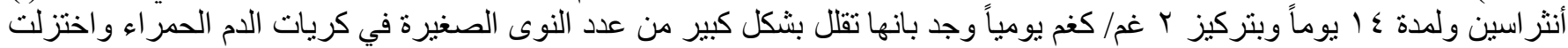

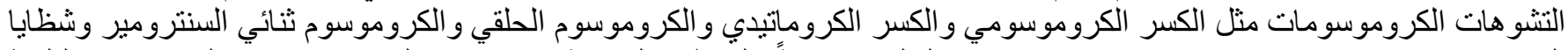

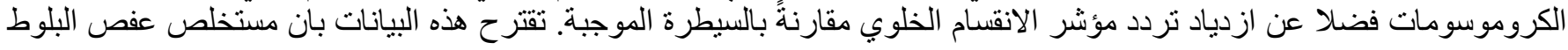




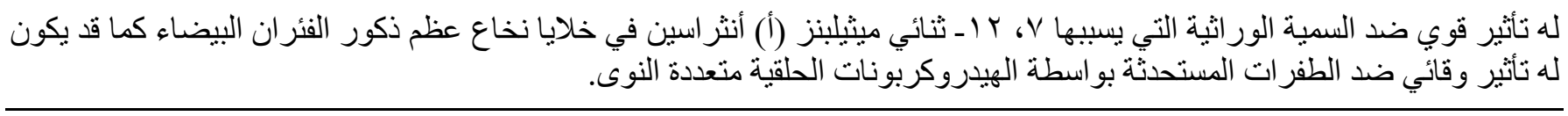

\section{Introduction}

Quercus infectoria (Q. infectoria) globally is referred as gall oak, traditionally was used as a common medical herbal in postpartum care and treatment of different diseases; the various Quercus species are originated in Iraq, Iran and Turkey, but now are widely spread and particularly common in Asia, Europe and North Africa. The galls growths on the new branch of the quercus tree in response to the attack by Adleria gallaetinctoria, the gall-wasp (1).

Pharmacologically, the galls of $Q$. infectoria reported as antidiabetic, and astringent agent (2), antimicrobial activities against viral, bacterial and parasites (3-5). Tannin $50-70 \%$, gallic acid 2-4\%, ellagic acid, starch, and sugar are the most common components showed within the galls of Q. infectoria (6). Tannins (gallotannic acid) is a phenolic compound characterized by its great roles in tissue protection from mutation, antitumor and protecting tissue from oxidation process (2).

Generally, any chemical that specifically or preferentially reduces the frequency of mutations is known as an antimutagen (7). Different polynuclear aromatic hydrocarbons (PAH) are found to be wildly distributed in the atmosphere environment and have been known to cause cancer (8).

DMBA (strong site specific carcinogenic agent) found a secondary product within the environment as a result of incomplete burning of hydrocarbons (9). The product requires metabolic activation to become a carcinogen (6). Cytochrome P4501B1 converts DMBA to form diol epoxides and other toxic such as reactive oxygen species (ROS). Chromosomal damage has been reported as a result of binding of diol epoxides to adenine residues of DNA (6).

In addition, DMBA metabolism generates ROS which spread along the generation site or diffuse to outside of the intact cells (10). ROS cause lipid peroxidation directly or indirectly through production of free radicals leading to genotoxic and clastogenic effects on bone marrow $(6,11$ 13). Recently, great attention has been focused to identify new antimutagenic and/or anticarcinogenic compounds through alternative pathways (14).

Many natural bioactive chemicals with genoprotective activity have been seen as a very effective way for halting human genetic diseases and cancer (7). These genoprotective substances commonly act as natural antimutagens and against processes of carcinogenesis. These substances are antimutagenic exert their effects through repairing mutation by inducing the mechanism of DNA repairing and replication (15).
Despite the fact, that QIGE has great health benefits with regards to its anti-microbial activities and the Quercus galls are widely distributed in northeastern of Iraq, to our knowledge no study yet has been done to understand the antimutagenic, anticlastogenic or anticarcinogenic activities of QIGE against DMBA. Accordingly, this study intended to evaluate the antimutagenic / anticlastogenic effects of QIGE against the potent carcinogen DMBA in in vivo study using bone marrow cells of mice by evaluation of the following cytogenetic biomarkers as mitotic index, chromosome aberration, and micronuclei.

\section{Materials and methods}

\section{Used chemical materials}

7,12-Dimethylbenz(a)anthracene and colchicine were supplied from ACROS organics company. DMBA was dissolved in corn oil then administered at $50 \mathrm{mg} / \mathrm{kg}$ dose intraperitoneally. All other chemicals were of the highest analytical grades which were commercially available.

\section{Q. infectoria galls material}

$Q$. infectoria galls are vegetable growths formed on twig of $Q$. infectoria tree, the galls are globular in shape and from 1.2 to $2.4 \mathrm{~cm}$ in diameter (Figure 1). The galls were collected locally from Gara mountain in Duhok province of Iraq in October 2016. The collected galls were washed with tap water and dried by air at home; then stored in a paper sack and kept at room temperature until use. The used galls were authenticated by Professor Saliem E. Shahbaz a taxonomist in Department of Forestry, College of Agricultural Engineering Sciences, University of Duhok, Iraq.

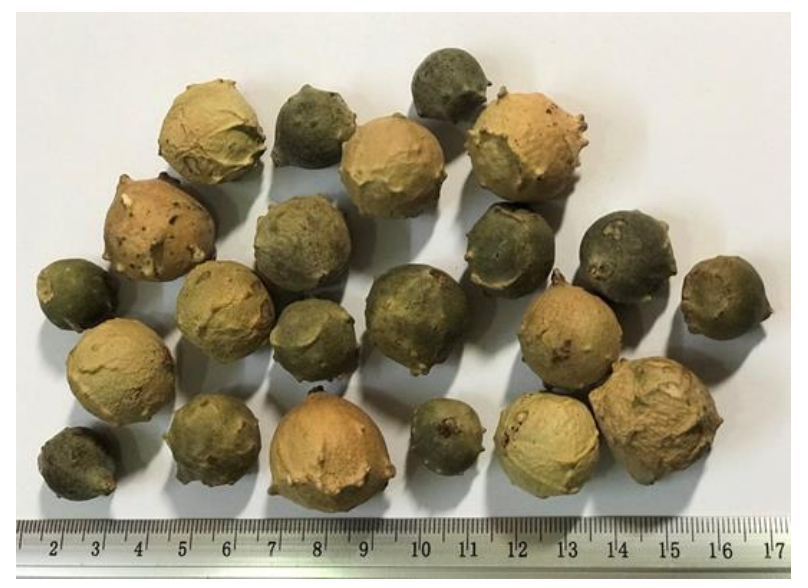

Figure 1: Q. infectoria Olivier (Fagaceae) galls. 


\section{Preparation of the QIG aqueous extract}

Electric grinder was used for grinding the cleaned airdried galls to make soft powder; the distilled water was used to homogenize the powder for 24 hours. The aqueous extract of the galls used in this study was prepared as follow: $200 \mathrm{ml}$ of the distilled water was used to suspend 50 gm of the powdered galls in Erlenmeyer flask by using magnetic stirrer over night at $45^{\circ} \mathrm{C}$. Following 24 hours, the obtained suspension was filtered by filter papers and gauzes firstly and then concentrated by rotary evaporator The weight of the crude extract was determined by following equation: Yield of extract $\%=$ weight of Petri dish with extract - weight of empty Petri dish $/ 50 * 100$ (16). The crude extract then was kept at $-20^{\circ} \mathrm{C}$ until the time of the use. In this study the extracts were dissolved in PBS as a solvent to obtain the experimental doses of $2 \mathrm{gm} / \mathrm{kg}$ body weight (b.w) that were given to Swiss albino mice by oral gavage.

\section{Experimental animals}

For the clastogenic and anticlastogenic assay, adult male Swiss albino mice Balb/c weighing 25-30 gm was used. The mice Mus musculus were provided by the animal house colony of College of Science, University of Duhok, Iraq. Five mice were housed per cage. The used mice were adapted to temperature and light in a well-controlled room, 12 hours dark /12 hours light, at temperature $25 \pm 2{ }^{\circ} \mathrm{C}$. Commercial pelleted was fed to mice and water ad libitum. This work was performed with the approval of Animal Ethical Committee of Duhok University, College of Veterinary Medicine, Iraq.

\section{Cytogenetic Assay protocol}

The main design of testing antimutagenic potential is based on standard test for evaluating the potential mutagenic properties of DMBA by induction of some cytogenetic markers in mice bone marrow in vivo (17). Twenty-five adult male mice were divided into five equal groups, each group of five mice. First group were orally treated by gavages with $0.5 \mathrm{ml}$ of PBS daily for 14 days and used as negative control. Second group, the positive control was injected intraperitoneally once with $0.5 \mathrm{ml}$ of DMBA (50 $\mathrm{mg} / \mathrm{kg} \mathrm{b.w})$. Third group were treated with oral dose of QIGE (2 gm/kg b.w/day) for 14 consecutive days. Fourth group (Pre- DMBA treatment) animals administrated with QIGE at concentration of $2 \mathrm{gm} / \mathrm{Kg}$ b.w for 14 days before injection with DMBA at day $15^{\text {th }}$. Fifth group (Post-DMBA treatment) animals injected with single dose of DMBA once and then administrated with QIGE at concentration 2 $\mathrm{gm} / \mathrm{kg}$ for 14 successive days. The used mice in each group were euthanized by cervical dislocation by the end of the experiment; samples of bone marrow were taken for cytogenetic analysis (MI and CA).
The same experimental design mentioned above was fallowed to calculate the number of polychromatous erythrocytes for the presence of micronuclei (MN).

\section{Toxicity of $Q$. infectoria galls}

To determine the toxicity of QIGE on mice used in this study, thirty-six Swiss Albino mice 25 - 30 gm weight were used and equally divided into six groups. Different QIGE doses $2,4,6,8,10$ and $12 \mathrm{gm} / \mathrm{kg}$ b.w. were administered orally to the mice, respectively. A minimum tolerance dose (MTD) experiment was conducted. QIG aqueous extract was administered orally in individual doses of $2 \mathrm{gm} / \mathrm{kg}$ of body weight. All treated mice were kept under observation for a period of two weeks for any abnormality like behavioral changes, physical signs of toxicity or death.

\section{Mitotic index (MI) assay}

To study Mitotic Index (MI), light microscope with (40x) power was used to score 1000 cells/animal in percentages, 1000 cells were numerated (divided and nondivided were counted), the percentage rate was determined and calculated for only the divided cells according to this equation: $\mathrm{MI} \%=$ No. of dividing cells $(\mathrm{P}+\mathrm{M}+\mathrm{A}+\mathrm{T}) /[$ Total No. of dividing cells + No. of non- dividing cells (1000 cells) $* 100$. where $(\mathrm{P}+\mathrm{M}+\mathrm{A}+\mathrm{T})$ is the collection of all cells in phase as prophase, metaphase, anaphase and telophase, respectively according to (18).

\section{Chromosomal aberration assay}

To detect the presence of $\mathrm{CA}$; all treated mice were intraperitoneally injected with $1 \mathrm{ml}$ of $4 \mathrm{gm} / \mathrm{kg}$ b.w. colchicine, three hours later, the injected mice were killed by cervical dislocation. Femurs from the dead mice were fleshed out from the muscles. In a centrifuge tube, the femurs were soaked with $5 \mathrm{ml} 0.075 \mathrm{M} \mathrm{KCl}$ solution. The tube was then incubated for 20 minutes at $37^{\circ} \mathrm{C}$, and then centrifuged for 10 minutes at $1000 \mathrm{rpm}$. Fresh Carnoy's fixative was added (3:1 methanol: acetic acid) following discarding the supernatant. The centrifugation process was done over three times. Later, the cells suspension was dropped onto clean slides that were dried by heating. The prepared slides were coded and stained by Giemsa stain then examined under oil immersion (100 x magnifications). For each animal, randomly 100 clearly distributed metaphase were scored/ animal (500 metaphase per treatment group) (19).

\section{Micronucleus test in bone marrow cells (MN)}

According to Schmid (20), MN test was investigated, bovine serum albumin was used to flush bone-marrow cells from femurs of sacrificed animals. Cells suspensions were centrifuged for $5 \mathrm{~min}$ at $1000 \mathrm{rpm}$, the obtained pellets were re-suspended in human albumin serum following discarding the supernatant. Giemsa stain then was used for air- dried, 
methanol fixed smears for 5 minutes, then microscopically examined under high magnification 100x power. Nearly, 1000 micronucleated polychromatic erythrocyte (MnPCEs) and polychromatic erythrocyte (PCE) were numerated for detection of micronuclei for each animal.

\section{Statistical Analysis}

For normality and homogeneity, firstly, all data were checked using residual plots and Bartlett's test, respectively. Genstat $12^{\text {th }}$ edition (VSN international Ltd, Hemel Hempstead, UK was used for all statistical analyses. I. For multiple comparison between groups of mice tested in this study, one-way analysis of variance (ANOVA) was performed followed by Duncan's test. For all experiments $\mathrm{P} \leq 0.05$ was considered as significant and all data are presented as Mean \pm S.E.M.

\section{Results}

\section{Toxicity study}

The toxic effect of QIG aqueous extract was firstly determined in this study; no mortality or great changes in performance of treated animals was recorded in this study, despite of receiving high dose $12 \mathrm{gm} / \mathrm{kg}$. Accordingly, $\mathrm{LD}_{50}$ cannot be calculated. The recorded data suggested that the aqueous extract of QIG is safe, thus, the clinical experiment can be done safely.

\section{Mitotic index}

This study focused on bone marrow as a target tissue because it is extremely vascularized and it has high population of very active cells that can be easily isolated and prepared. To detect the rate of the cells with mitosis and calculate cellular proliferation, the mitotic index test was conducted. The recorded data showed that the Mitotic index value $(\mathrm{QIGE}=8.23 \pm 0.405)$ of animals treated with QIGE alone with the dose of $2 \mathrm{gm} / \mathrm{kg}$ was lower than that of negative control (PBS $=8.93 \pm 0.52$ ), but not significant. Moreover, it was found that a significant decrease in mitotic index of DMBA treated animals (pre $=5.23 \pm 0.284$ ) and (post $=5.7 \pm 0.264$ ) compared to the positive control group (DMBA alone $=2.86 \pm 0.371) \quad$ indicating anticytotoxicity effect of QIGE towards DMBA induced damage (Table 1).

Table 1: Chromosome aberration and Mitotic index in bone marrow of mice treated with $Q$. infectoria galls aqueous extract $(2 \mathrm{gm} / \mathrm{kg})$, PBS (negative control), DMBA $(50 \mathrm{mg} / \mathrm{kg})$ (positive control), pre-treatment (QIGE+ DMBA) and post-treatment (DMBA + QIGE). Different letters within each column differ significantly $(\mathrm{P}<0.05)$ according to Dunnett test

\begin{tabular}{lccccc}
\hline & PBS (N.Co.) & QIGE & QIGE+DMBA & DMBA+QIGE & DMBA (P.Co.) \\
\hline Chromatid break & $3.36 \pm 0.28^{\mathbf{A}}$ & $3.45 \pm 0.24^{\mathbf{A}}$ & $6.35 \pm 0.33^{\mathbf{B}}$ & $3.53 \pm 0.41^{\mathbf{A}}$ & $5.78 \pm 0.32^{\mathbf{B}}$ \\
Chromosome break & $3.38 \pm 0.45^{\mathbf{A}}$ & $3.14 \pm 0.57^{\mathbf{A}}$ & $6.25 \pm 0.41^{\mathbf{B}}$ & $4.03 \pm 0.94^{\mathbf{A B}}$ & $12.13 \pm 0.99^{\mathbf{C}}$ \\
Centromere break & $2.05 \pm 0.33^{\mathbf{B}}$ & $3.99 \pm 0.09^{\mathbf{C}}$ & $0.57 \pm 0.21^{\mathbf{A}}$ & $2.55 \pm 0.31^{\mathbf{B}}$ & $4.78 \pm 0.44^{\mathbf{C}}$ \\
Ring chromosome & $0.63 \pm 0.29^{\mathbf{A}}$ & $1.04 \pm 0.06^{\mathbf{A B}}$ & $0.48 \pm 0.11^{\mathbf{A}}$ & $1.40 \pm 0.35^{\mathbf{B}}$ & $0.54 \pm 0.05^{\mathbf{A}}$ \\
Dicentric chromosome & $0.08 \pm 0.08^{\mathbf{A}}$ & $0.32 \pm 0.07^{\mathbf{A}}$ & $0.42 \pm 0.07^{\mathbf{A}}$ & $1.13 \pm 0.17^{\mathbf{B}}$ & $0.57 \pm 0.29^{\mathbf{A}}$ \\
Acentric fragment & $0.52 \pm 0.16^{\mathbf{A B}}$ & $0.93 \pm 0.04^{\mathbf{D}}$ & $0.24 \pm 0.02^{\mathbf{A B}}$ & $0.66 \pm 0.17^{\mathbf{C D}}$ & $0.09 \pm 0.09^{\mathbf{A}}$ \\
Pulverization & $0.00 \pm 0.00^{\mathbf{A}}$ & $0.00 \pm 0.00^{\mathbf{A}}$ & $0.00 \pm 0.00^{\mathbf{A}}$ & $0.00 \pm 0.00^{\mathbf{A}}$ & $4.33 \pm 1.4^{\mathbf{B}}$ \\
Total aberrant metaphase & $10.02 \pm 0.7^{\mathbf{A}}$ & $12.88 \pm 0.4^{\mathbf{A B}}$ & $14.33 \pm 0.85^{\mathbf{B}}$ & $13.30 \pm 0.31^{\mathbf{A B}}$ & $31.23 \pm 1.9^{\mathbf{C}}$ \\
Mitotic index & $8.93 \pm 0.52^{\mathbf{A}}$ & $8.23 \pm 0.41^{\mathbf{A B}}$ & $5.23 \pm 0.28^{\mathbf{B}}$ & $5.7 \pm 0.26^{\mathbf{B}}$ & $2.86 \pm 0.37^{\mathbf{C}}$ \\
\hline
\end{tabular}

\section{Chromosomal aberrations}

Concerning this study, the total aberrations with QIGE was $12.88 \pm 0.49$, QIGE alone induced slightly significant chromosomal aberrations comparing with the negative control 10.02 \pm 0.78 . While, the pre- and post-treatment of QIGE with the DMBA imparted protective effects which were found to be more significant in post-administration of the extract (post $=13.30 \pm 0.31$ ). The post-treatment caused a great reduction in the number of metaphases with chromosome aberrations relative to the DMBA such as chromatid break, chromosome break, centromere break, ring chromosome, dicentric chromosome, acentric fragment and pulverization defect comparing with DMBA treated animals (positive control). The decreases in aberrations after 14 days of QIGE could be due to the clearance of drug from the body, post-replication repair process.
The results of analysis of chromosome aberrations are presented in table 1 and figure 2 .

\section{Micronucleated polychromatic erythrocytes (MnPCEs)}

The data of micronucleus test are presented in table 2 and figure 3 which summarized the impact of DMBA alone, pre-treatment (QIGE+DMBA) and post-treatment (DMBA+QIGE) on the frequency of DMBA-induced micronucleated polychromatic erythrocytes (MnPCEs). A great elevation $(\mathrm{P}<0.05)$ in the number of $\mathrm{MN}$ was detected in DMBA treated animals compared to untreated negative control; the pre- and post-treatment with QIGE data found a significant $(\mathrm{P}<0.05)$ reduction in the incidence of the total $\mathrm{MN}$ cells compared to the positive control. 
However, the pre-treatment (133.33 \pm 6.984$)$ found to be more protective against DMBA-induced bone marrow micronuclei than that of post-treatment $(181.67 \pm 4.91)$, thus, the QIGE was found to play a potential protective role against the mutagenic agent, DMBA.

Table 2: Inhibition effects of $Q$. infectoria galls extract (QIGE) alone and in combination pre-treatment (QIGE+DMBA) and post-treatment (DMBA+QIGE) on DMBA induced bone marrow micronucleated polychromatic erythrocyte

\begin{tabular}{lcccccc}
\hline & Single MN & Di MN & Tri MN & Tetra MN & Poly MN & Total abnormal \\
\hline PBS (N.Co.) & $43 \pm 8.51^{\mathbf{A}}$ & $15.67 \pm 7.056^{\mathbf{A}}$ & $11.67 \pm 1.20^{\mathbf{A}}$ & $3.33 \pm 2.02^{\mathbf{A}}$ & $17.00 \pm 5.29^{\mathbf{A}}$ & $90.67 \pm 19.2^{\mathbf{A}}$ \\
QIGE 2gm/kg & $39.33 \pm 4.10^{\mathbf{A}}$ & $15.33 \pm 5.89^{\mathbf{A}}$ & $11.33 \pm 1.86^{\mathbf{A}}$ & $2.33 \pm 1.33^{\mathbf{A}}$ & $16.33 \pm 2.63^{\mathbf{A}}$ & $84.67 \pm 10.2^{\mathbf{A}}$ \\
QIGE+ DMBA & $71.33 \pm 7.51^{\mathbf{B}}$ & $21.00 \pm 4.58^{\mathbf{A}}$ & $11.33 \pm 3.84^{\mathbf{A}}$ & $4.67 \pm 0.33^{\mathbf{A}}$ & $25.00 \pm 2.52^{\mathbf{B}}$ & $133.33 \pm 6.9^{\mathbf{B}}$ \\
DMBA+QIGE & $56.67 \pm 6.01^{\mathbf{A B}}$ & $13.33 \pm 4.26^{\mathbf{A}}$ & $11.00 \pm 7.02^{\mathbf{A}}$ & $3.67 \pm 0.88^{\mathbf{A}}$ & $97.00 \pm 4.16^{\mathbf{A}}$ & $181.67 \pm 4.9^{\mathbf{C}}$ \\
DMBA (P.Co.) & $102.00 \pm 7.02^{\mathbf{C}}$ & $46.00 \pm 3.056^{\mathbf{B}}$ & $16.00 \pm 5.29^{\mathbf{A}}$ & $9.33 \pm 1.33^{\mathbf{B}}$ & $80.00 \pm 13.01^{\mathbf{B}}$ & $253.33 \pm 13.8^{\mathbf{D}}$ \\
\hline
\end{tabular}

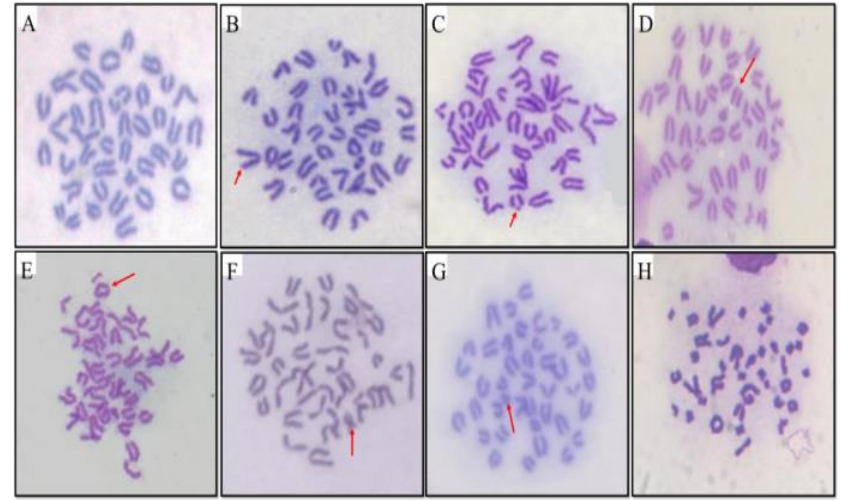

Figure 2: Metaphases from mice treated with DMBA showing different types of structural chromosomal aberrations. A: Normal chromosomes, B: Chromatid break, C: Chromosome breaks, D: Centromere break, E: Ring chromosome, F: Dicentric break, G: Acentric fragments, H: Pulverization. 1000x.

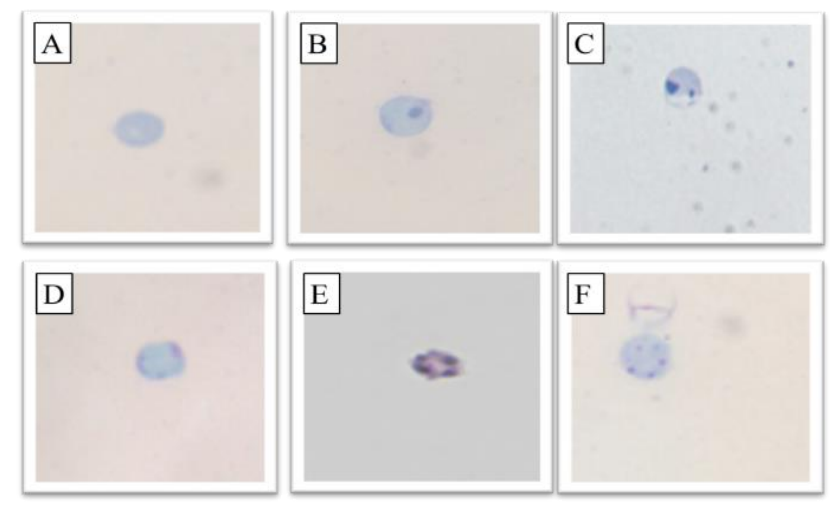

Figure 3: Types of micro-nucleated cell induced by 7,12dimethylbenz(a)anthracene (DMBA) in male albino mice A: NCE normochromatic B: Mono micronuclei, C: Di micronuclei, D: Tri micronuclei, E: Tetra micronuclei, F: PCE polychromatic erythrocyte. 1000x.

\section{Discussion}

Generally, chromosome aberrations and point mutations are regarded as one of most common causes of tumors. (21). In vivo studies recommended to use mammalians (mice) bone marrow cells to study the possible effects of mutagenic or antimutagenic agents on chromosomes (22).

The present study found that QIGE was safe to bone marrow cells of mice at the tested dose $2 \mathrm{gm} / \mathrm{kg}$, also mice behavior was normal, the potential toxicity of QIG aqueous extract was also detected in mice at the dose $10 \mathrm{gm} / \mathrm{kg}$ through histopathological study, evaluation of hematological and biochemical parameters, which also confirm our result (23). Moreover, the present data showed that the administrating of QIGE strongly reduced the influence of DMBA-induced chromosome aberration; the pre-and post-treatment with QIGE combination significantly reduced number of bone marrow micronuclei induced by intraperitoneal injection of DMBA, suggesting the protective antigenotoxic properties of the QIGE. Polyphenols, tannins and flavonoids are the main components of the $Q$. infectoria galls that are characterized by antioxidant and antimutagenic activities and are regarded as antigenotoxic agents (24). Besides, great amount of polyphenols was found in galls extract with a strong antioxidant activities (25). Polyphenols and Hydrolysable tannins belong to a group of compound with protective characteristics $(26,27)$. Phenolic phytochemical compounds have the ability to remove free radicals, activate antioxidant enzymes through a defense mechanism against reactive oxygen species (28). Cytochrome P450 was reported to be induced by polyphenols leading detoxification of the carcinogens inside cells (29). Furthermore, events have demonstrated that tannin molecules act as antimutagenic agent through reducing the mutagenic activity of some mutagens by its antioxidative properties (30). Thus, it is suggested that polyphenols, tannins and flavonoids component of QIGE act as potent antioxidant agents by scavenging of free radical, inducing 
gene regulation, and by elimination of drug from the body and as a curative agent by activation the post-replication repair enzymes.

\section{Conclusion}

The present study found that the oral administration of QIG aqueous extract reported inhibitory and protective effects on the cytotoxic and clastogenic damage produced by DMBA which would be a promising approach toward inhibiting the genetic damage by chemical environmental pollutants. Surely, more works are required to study the same activity of $Q$. infectoria galls on different study models using various lab animals, to identify the active constituents of QIGE in details.

\section{Acknowledgments}

The authors are thankful to Duhok Research Center, College of Veterinary Medicine, Duhok University, for providing the needful lab facilities for this research. Also, the authors gratefully acknowledge the Department of Biology, College of Science, Duhok University for their support in providing their animal house laboratory and all its facilities to complete our practical work.

\section{Conflict of interest}

No conflict of interest.

\section{References}

1. Baharuddin N, Abdullah H, Abdul Wahab WN. Anti-Candida activity of Quercus infectoria gall extracts against Candida species. J Pharma Bio Sci. 2015;7(1):15. 10.4103/0975-7406.148742

2. Srivastava RC, Husain MM, Hasan SK, Athar M. Green tea polyphenols and tannic acid act as potent inhibitors of phorbol esterinduced nitric oxide generation in rat hepatocytes independent of their antioxidant properties. Cancer Letters. 2000;153(1-2):1-5. 10.1016/s0304-3835(99)00400-0

3. Hussein G, Miyashiro H, Nakamura N, Hattori M, Kakiuchi N, Shimotohno K. Inhibitory effects of Sudanese medicinal plant extracts on hepatitis $\mathrm{C}$ virus (HCV) protease. Phytotherap Res. 2000;14(7):510-6. 10.1002/1099-1573(200011)

4. Mengeloğlu F. Antimicrobial activity of galls of Quercus infectoria. Dicle Med J. 2011;38(3):309-11. 10.5798/0921.2011.03.0038

5. Redwane A, Lazrek HB, Bouallam S, Markouk M, Amarouch H, Jana M. Larvicidal activity of extracts from Quercus lusitania var. infectoria galls (Oliv.). J Ethnopharmacol. 2002;79(2):261-3. 10.1016/s0378-8741(01)00390-7

6. Guerin MR. Energy sources of polycyclic aromatic hydrocarbons. In: Environment, chemistry, and metabolism. New York: Academic Press; 1978. 3-42 p. 10.1016/B978-0-12-279201-4.50008-6

7. Clarke $\mathrm{CH}$, Shankel DM. Antimutagenesis in microbial systems. Bacteriol Rev. 1975;39(1):33-53. 10.1128/mmbr.39.1.33-53.1975

8. Abdel-Shafy HI, Mansour MS. A review on polycyclic aromatic hydrocarbons: Source, environmental impact, effect on human health and remediation. Egyptian J Petroleum. 2016;25:107-23. $\underline{10.1016 / j . e j p e .2015 .03 .011}$
9. Yu H, Yan J, Jiao Y, Fu PP. Photochemical reaction of 7,12dimethylbenz[a]anthracene (DMBA) and formation of DNA covalent adducts. Inter $\mathrm{J}$ Environ Res Pub Heal. 2005;2(1):114-22. 10.3390/ijerph2005010114

10. Schieber M, Chandel NS. ROS function in redox signaling and oxidative stress. Cur Biol. 2014;24(10):R453-62. 10.1016/j.cub.2014.03.034

11. Iminjan M, Amat N, Li XH, Upur H, Ahmat D, He B. Investigation into the toxicity of traditional Uyghur medicine Quercus infectoria galls water extract. PLoS ONE. 2014;9(3):e90756. 10.1371/journal.pone.0090756

12. Valdiglesias V, Mndez J, Psaro E, Laffon B. The importance of the in vitro genotoxicity evaluation of food components: The selenium. J Nutr. 2009;140(1):213-233. 10.3945/jn.109.110569

13. Thakkar JH, Solanki HK, Tripathi P, Patel NJ. Evaluation of antimutagenic potential of Annona squamosa leaf extract. Inter J Biol Pharma Res. 2010;1(2):114-23. 10.22159/ajpcr.2019.v12i2.29026

14. Berti AP, Palioto GF, Rocha CLMSC. Antimutagenicity and antigenotoxicity of Aloe arborescens miller and Aloe barbadensis miller in Aspergillus nidulans and wistar rats. Gen Mol Res. 2016;15(3). 3-5. 10.4238/gmr.15038522

15. De Flora S. Mechanisms of inhibition of mutagenesis and carcinogenesis: Classification. Mut Res Environ Mut Rel Sub. 2003;203(3):205. 10.1016/s0027-5107(97)00292-3

16. McClure JW. Physiology and functions of flavonoids. In: Boston, MA. The flavonoids. New York: Springer; 1975. 970-1055 p.

17. Bannerman RM. Mutagenicity: New horizons in genetic toxicology. Am J Med Gen. 2005;15(2):350-1. 10.1002/ajmg.1320150224

18. Shubber EK, Juma AS. Cytogenetic effects of plant extract of Urtica dioca on mouse somatic cells. Nucleus. 1999;42(3)182-187. $10.1508 \% 2$ Fcytologia.70.385

19. Evans EP, Breckon G, Ford CE. An air-drying method for meiotic preparations from mammalian testes. Cytogen Gen Res. 1964;3(5):289-94. 10.1159/000129818

20. Schmid W. The micronucleus tests. Mut Res. 1975;31(1):9-15. 10.1016/0165-1161(75)90058-8

21. Bhuvaneswari V, Velmurugan B, Abraham SK, Nagini S. Tomato and garlic by gavage modulate 7,12-dimethylbenz[a]anthracene-induced genotoxicity and oxidative stress in mice. Brazilian J Med Biol Res. 2004;37(7):1029-34. 10.1590/s0100-879x2004000700012

22. Mayer C, Schmezer P, Freese R, Mutanen M, Hietanen E, Obe G. Lipid peroxidation status, somatic mutations and micronuclei in peripheral lymphocytes: A case observation on a possible interrelationship. Cancer Let. 2000;152(2):169-73. 10.1016/s03043835(00)00332-3

23. Iminjan $\mathrm{M}$, Amat $\mathrm{N}$, $\mathrm{Li} \mathrm{XH}$, Upur $\mathrm{H}$, Ahmat $\mathrm{D}$, He B. Investigation into the toxicity of traditional uyghur medicine Quercus infectoria galls water extract. PLoS ONE. 2014;9(3) 10.1371/0090756.e90756

24. Fathabada AE, Shariatifar N, Mardania K and Mohammad PI. Study on antibacterial and antioxidant activity of Oak gall (Quercus infectoria) extracts from Iran. Int J Curr Sci. 2015;14:44-50. https://www.researchgate.net/publication/338336622

25. Kaur G, Athar M, Alam MS. Quercus infectoria galls possess antioxidant activity and abrogates oxidative stress-induced functional alterations in murine macrophages. Chem Bioll Inter. 2008;171(3):272-82. 10.1016/j.cbi.2007.10.002

26. Mathew S, Kuttan G. Antioxidant activity of Tinospora cordifolia and its usefulness in the amelioration of cyclophosphamide induced toxicity. J Exp Clin Can Res. 1997;16(4):407-11.

27. Premkumar K, Pachiappan A, Abraham SK, Santhiya ST, Gopinath PM, Ramesh A. Effect of Spirulina fusiformis on cyclophosphamide and mitomycin-C induced genotoxicity and oxidative stress in mice. Fitoterapia. 2001;72(8):906-11. 10.1016/s0367-326x(01)00340-9

28. Oh HT, Kim SH, Choi HJ, Chung MJ, Ham SS. Antioxidative and antimutagenic activities of $70 \%$ ethanol extract from masou salmon (Oncorhynchus masou). Toxicol Vitro. 2008;22(6):1484-8. $\underline{10.1590 / \mathrm{S} 1516-89132015060309}$ 
29. Gupta S, Chaudhuri T, Seth P, Ganguly DK, Giri AK. Antimutagenic effects of black tea (World blend) and its two active polyphenols theaflavins and the amrubicin's in Salmonella assays. Phytotherapy Res. 2002;16(7):655-61. 10.1002/ptr.1038
30. Hemmati AA, Houshmand G, Nemati M, Bahadoram M, Dorestan N, Rashidi-Nooshabadi MR. Wound healing effects of Persian oak (Quercus brantii) ointment in rats. Jundishapur J Nat Pharm Prod. 2015;10(4):e25508. 10.17795/jjnpp-25508 